\title{
The use of physical activity trackers devices and physical activity levels in adolescents and adults
}

\section{El uso de rastreadores de actividad física y niveles de actividad física en adolescentes y adultos}

\section{O uso de monitores de atividade física e níveis de atividade física em adolescentes e adultos}

\author{
Lopes, V. P. ${ }^{1}$, Sá, C. ${ }^{2}$ \\ ${ }^{1}$ Instituto Politécnico de Bragança, Campus de Santa Apolónia, Bragança, Portugal and Research \\ Center in Sports Sciences Health Sciences and Human Development (CIDESD), Portugal, ${ }^{2}$ Research \\ Center in Sports Sciences Health Sciences and Human Development (CIDESD), Portugal.
}

\begin{abstract}
The purpose was to investigate the use of physical activity trackers (PAT) and to analyze the relationship between its use and physical activity (PA) levels. Participants were $\mathrm{N}=1498$ ( $\mathrm{N}=841$ females) aged $14-85$ years. Interest, use and preferences for PAT were measured by questionnaire. PA was measured using IPAQ short version. KruskalWallis Test was used to test the differences in PA levels between participants. Out of all the participants who practice PA/exercise regularly, 59\% do not use PAT, 27\% were using, and 14\% have used. Adolescents, middle-aged females and older males, who use PAT did significantly more vigorous PA than participants who not use. Young adults who use PAT did significantly more moderate and vigorous PA than participants who not use. And middle-aged males who use PAT did significantly more total week PA, vigorous PA and walking PA than participants who not use. About half of the participants that exercise regularly use PAT. Despite participants that use PAT tend to have higher levels of habitual PA, it is not conclusive that the use of PAT leads to do more PA.
\end{abstract}

Keywords: physical activity trackers; fitness; health promotion; exercise

\section{RESUMEN}

El propósito fue investigar el uso de rastreadores de actividad física (RAF) y analizar la relación entre su uso y los niveles de actividad física (AF). Los participantes fueron $\mathrm{N}=1498(\mathrm{~N}=841$ mujeres) de 14 a 85 años. El interés, el uso y las preferencias de RAF se midieron mediante un cuestionario. La AF se midió utilizando la versión corta de IPAQ. La prueba de Kruskal-Wallis se utilizó para evaluar las diferencias en los niveles de AF entre los participantes. De todos los participantes que practican AF regularmente, el 59\% no usa RAF, el 27\% lo estaba usando y el 14\% lo ha usado. Los adolescentes, las mujeres de mediana edad y los hombres mayores, que usan RAF, hicieron significativamente más AF intensa que los participantes que no lo usan. Los adultos jóvenes que usan RAF tuvieron niveles de AF moderada y vigorosa significativamente más elevada que los participantes que no lo usan. Los hombres de mediana edad que usan RAF tuvieron significativamente más AF global y AF vigorosa y caminaban más que los participantes que no lo usan. Alrededor de la mitad de los participantes que hacen ejercicio regularmente usan RAF. 


\section{Activity trackers and physical activity}

A pesar de que los participantes que usan RAF tienden a tener niveles más altos de AF, no es concluyente que el uso de RAF conduzca a más PA.

Palabras clave: sensores de movimiento; aptitud física; promoción de la salud; ejercicio físico.

RESUMO (1500 palavras) (mesma ordem como títulos)

O objetivo deste estudo foi avaliar o uso de dispositivos de avaliação da atividade física (PAT) e analisar a relação entre o seu uso e os níveis de atividade física (AF). Os participantes foram $\mathrm{N}=1498$ ( $\mathrm{N}=841$ mulheres) com idades compreendidas entre 14 e 85 anos. O interesse, uso e preferências pelo PAT foram medidos por questionário. A AF foi avaliada usando a versão curta do IPAQ. O teste de Kruskal-Wallis foi utilizado para testar as diferenças nos níveis de $\mathrm{AF}$ entre os participantes. De todos os participantes que praticam AF / exercitam-se regularmente, 59\% não usam PAT, $27 \%$ estavam a usar e $14 \%$ já usaram. Adolescentes, mulheres de meia idade e homens mais velhos, que usam o PAT, fizeram AF significativamente mais vigorosa do que os participantes que não usam. Jovens adultos que usam PAT fizeram AF significativamente mais AF moderada a vigorosa do que os participantes que não usam. $\mathrm{E}$ os homens de meia-idade que usam PAT fizeram significativamente mais AF total na semana, AF vigorosa e AF de caminhada que os participantes que não usam. Cerca de metade dos participantes que se exercitam regularmente usam o PAT. Apesar dos participantes que usam o PAT tenderem a ter níveis mais altos de AF habitual, não é conclusivo que o uso do PAT indica mais AF.

Palavras chave: sensores de movimento; aptidão física; promoção da saúde; exercício físico

\section{INTRODUCCIÓN}

According to the World Health Organization physical inactivity is a major risk factor of death globally (WHO, 2014). Data from adults in high-income countries suggest the majority of awake time is spent being sedentary (Matthews et al., 2008). The pandemic of physical inactivity is associated with a range of chronic diseases and early deaths (Ding et al., 2016). Estimates from 2012 indicated that not meeting physical activity (PA) recommendations is responsible for more than 5 million deaths globally each year (Lee et al., 2012). The benefits of physical activity (PA) on health and well-being on different ages are extensively detailed in the literature, they include improved cardiorespiratory and muscular fitness, positive effects on weight status, bone health, and prevent and treat heart disease, stroke, diabetes and breast and colon cancer (Janssen \& LeBlanc, 2010; Reiner et al., 2013). Importantly, the beneficial effects of PA are also related to social interactions and mental and psychological well-being (Delle Fave et al., 2018; Diego et al., 2018; Herbert et al., 2020; Lawton et al., 2017; López et al., 2017; Moral-Campillo et al., 2020). Despite the benefits of PA in health and well-being, research indicates that sedentary behaviour is highly prevalent in all ages (Guthold et al., 2020; Hallal et al., 2012; WHO, 2018). According to the most up-to-date U.S. PA data measured by accelerometers (2005-2006
NHANES), only $7.5 \%$ youth between the ages of $12-$ 15 and $5.1 \%$ youth between the ages of 16-19 meet the U.S. physical activity guidelines, (Katzmarzyk et al., 2016). Recent reports indicat that Spanish (Añez et al., 2020; Roman-Viñas et al., 2016) and Portuguese children and adolescents (Mota et al., 2016) do not reach sufficient PA levels and spend larger amounts of time in sedentary behaviors compared with recommendations.

PA is a complex multifactorial behavior that is influenced by a variety of biological, behavioral, social and environmental factors and interactions among factors (Bauman et al., 2002; Trost et al., 2002). For its promotion several strageies using different apporachs were developed and implemented worlwide (Heath et al., 2012). Behavioural and social approaches, social support for PA within communities and worksites, and school-based strategies that encompass physical education, classroom activities, after-school sports, and active transport are strategies reported with some effectiveness. Despite the acceptable level of success on intervention programs to increase PA of people of different ages, and from various social groups and countries (Heath et al., 2012), long term effect of the interventions are less effective (Van Sluijs et al., 2007). Wahlich et al. (2019) found evidence of physical activity 


\section{Lopes, Sá}

intervention effects beyond 12 months, sustained up to 4 years. However, the number of PA interventions with objective measures with follow-up beyond 12 months are scarce to draw conclusions.

Motivation is considered to be a key factor for PA adherence (Quested et al., 2017). Laura and Fabio (2016) using a self-determination theory approach found effective effect of an intervention PA program. In fact, a growing body of research has demonstrated the importance of motivation for a range of health behaviours, such as PA and healthy eating (Fortier et al., 2012; Silva et al., 2010; Zhong \& Wang, 2019). Enjoyment, and intrinsic motivation associated with it, showed to be a significant predictor of intention to be physical active (Rodrigues et al., 2020).

Physical activity trackers (PAT) that provide feedback to users have also been used in longitudinal interventions to motivate research participants and to assess their compliance with program goals (David, 2012). PAT, as pedometers, accelerometers, smartphone applications and heart rate monitors, can be an important complement for people to motivate for PA, modify their sedentary behaviour, and to monitor their PA and exercise (Brickwood et al., 2019; Wen et al., 2017). According a recent systematic review and meta-analysis research (Brickwood et al., 2019), utilizing a PAT as either the primary component of an intervention or as part of a broader PA intervention has the potential to increase PA participation. Brickwood et al. (2019) found that there was a significant increase in daily step count, moderate and vigorous PA, and energy expenditure and a no significant decrease in sedentary behaviour following the intervention versus control comparator across all studies in the metaanalyses.

PAT may provide an alternative means of support and motivation to individuals both looking to increase their activity levels or to maintain activity levels following a structured lifestyle intervention. Randomized controlled trials have shown that these devices have promise in relation to increasing PA levels (Cadmus-Bertram et al., 2015); however, participant numbers in individual studies tend to be low, making it difficult to adequately assess the benefits of these devices. Despite the potential and the wide range of PAT available, little is known about the interest, usage, preferences, and their efficacy in PA
Thus, taking into account the above, this study aimed (1) to investigate the use of PAT in Portuguese adolescents and adults, in particular how often people use them and how they use them to monitor exercise/PA, and (2) to analyse the relationship between its use and the levels habitual PA. Considering the previous literature results, we hypothesize that PAT use is positively associated with physical activity levels.

\section{MATERIAL Y MÉTODOS}

Type of Study

Cross-sectional survey design, using questionnaires. Data were collected between January and December of 2017.

\section{Participants}

Participants were voluntaries selected from schools, universities, clubs, work sites and communities' settings. A snowball sampling method was used. Inclusion criteria were being 14 years old or more and residing in different regions of Portugal mainland (North, Centre, Lisbon, Alentejo and Algarve), Madeira islands and Azores islands.

Questionnaires were distributed and answered in paper format and online. In both cases, participants gave their informed consent. The participants that answered online were invited by email, explaining the objectives of the study and including a link to the online questionnaire. The participants were requested to forwarded the email to acquaintances and friends. The participants that answer in paper format were asked to indicate friends and acquaintance that could answer the questionnaires.

Participants were $\mathrm{N}=1498$, of both sexes $(\mathrm{N}=841$ females) with ages between 14 and 85 years. Participants were categorized by age into adolescents (ages 14-18 years; $\mathrm{N}=135$ ), young adults (ages 19-40 years; $\mathrm{N}=1047$ ), middle-aged adults (ages 41-65 years, $\mathrm{N}=271$ ), and older adults (aged older than 65 years, $n=45$ ). This is the most common procedure for stratifying samples by age group, which correspond to the Erikson's stages of psychosocial development (Ahroni, 1996; Erikson \& Erikson, 1998). The 


\section{Activity trackers and physical activity}

demographics characteristics of participants are displayed in Table 1.

The ethics committee of the institution of the first author approved the study. All procedures performed in studies involving human participants were in accordance with the ethical standards of the institutional and/or national research committee and with the 1964 Helsinki declaration and its later amendments or comparable ethical standards. participants these domains were switched to schoolrelated physical activity, including activity during physical education classes and breaks (Hagströmer et al., 2008).

Data were summarized according to the physical activities recorded (walking, moderate, and vigorous activities) and the estimated time spent sitting per week. Frequency (measured in days per week) and duration (time per day) were collected separately for each specific type of activity. Data were then used to

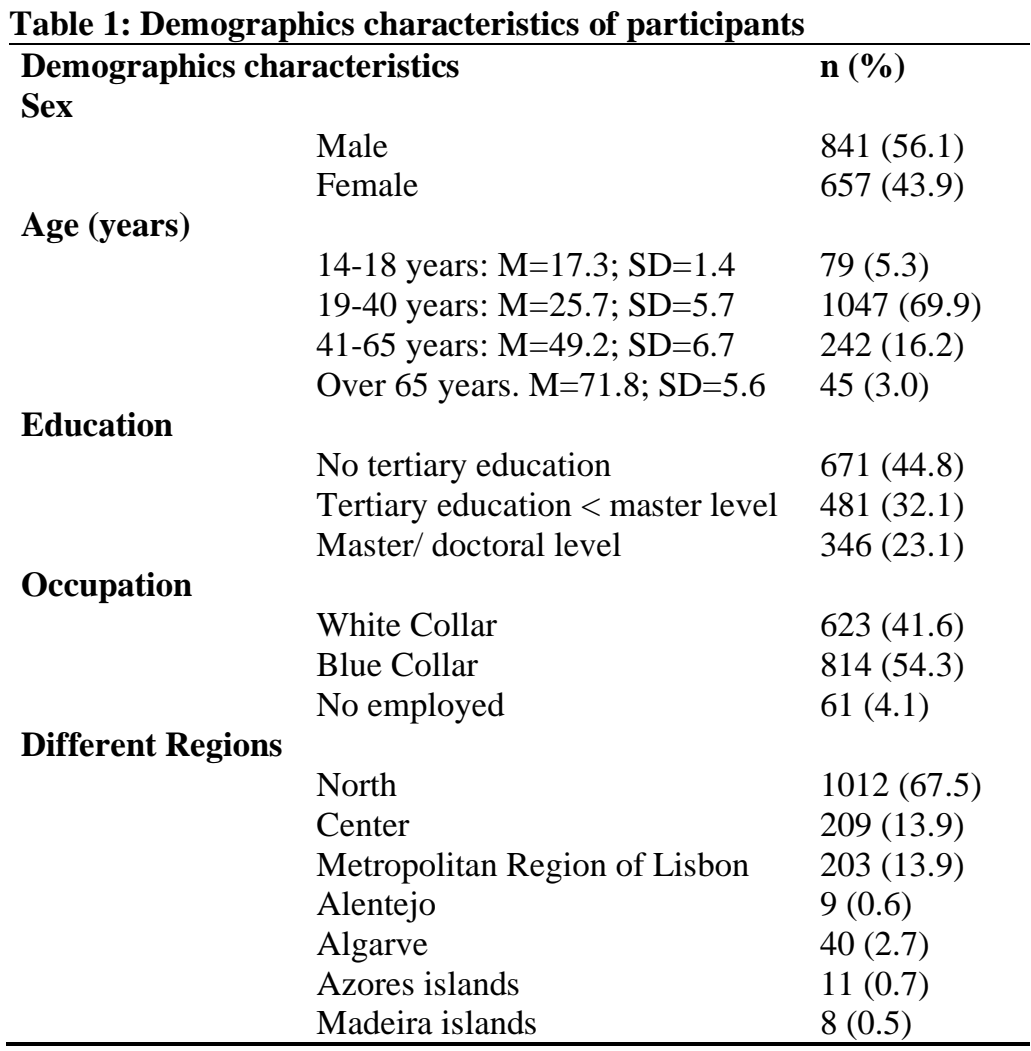

\section{Physical Activity}

Physical activity (PA) was measured using the short version of the International Physical Activity Questionnaire (IPAQ) (Craig et al., 2003; Hagströmer et al., 2008). The questionnaire was self-administrated with reference to the last 7 days of recalled PA. The IPAQ short version asks about three specific types of activity carried out in three domains (leisure time, domestic and gardening/yard activities, work-related and transport-related activity) and sitting, providing information on the time spent walking, in vigorousand moderate-intensity PA and in sedentary activity. In the context of the present study, and for adolescent estimate total weekly PA by weighting the reported minutes per week within each activity category by a MET energy expenditure assigned to each category of activity (walking $=3.3$ METs, moderate $\mathrm{PA}=4.0$ METs and vigorous $\mathrm{PA}=8.0 \mathrm{METs}$ ). The weighted MET-minutes per week (MET'min'wk-1) were calculated as duration $\times$ frequency per week $\times$ MET intensity, which were summed across activity levels to produce a weighted estimate of total PA per week (MET. $\left.\min \cdot \mathrm{wk}^{-1}\right)$. The sitting question is a separate indicator and it is not included in the PA score. The IPAQ short version has been tested extensively with reported reliability of 0.80 and validity of 0.30 (Craig et al., 2003). 


\section{Lopes, Sá}

Besides IPAQ, participants were also asked if they do or they did in the past exercise regularly (yes/no), and at what weekly frequency.

\section{Use of physical activity trackers}

Interest, use and preferences for PAT were measured by a questionnaire developed by the authors of the present study only for the purposes of the present investigation. The clarity of the questions was previously tested on a set of volunteers $(\mathrm{N}=30)$ in the presence of the study authors. The volunteers indicated when they had difficulty in interpreting the questions. Another five researchers from our research group also gave their suggestions and agreement on the formulation of the questions. Afterwards, the entire form was adjusted and only then made available to the participants.

The sequence of the questions were the following: first, participants were asked if they do or did in the past, do exercise regularly (yes/no). PA tracker use was assessed in the participants that do or did exercise regularly, by asking if they had ever used a PA tracker (use, had used and never used). Participants who use or had used PA tracker were further asked what type of PA tracker they use or had used, if they acquired the PA tracker before or after they started exercise regularly, what parameters they register (time length of the exercise, speed, distance, hearth rate, calories, accumulated climb, power, VO2), for how long they have been using the PA tracker regularly at least once a week (less than a month, between 3 and 4 months, between 6 and 12 month, between 1 and 2 years, and more than 2 years), how often they used the PA tracker (only during exercise, during waking hours, only at night, always all day and all night).

Participants were also asked about their perception of the possible influence of activity trackers on the motivation for PA/exercise (yes/no), and if they increased the amount of PA/exercise after starting using it (yes/no), and how much (less than an hour per week, 1 to 2 hours of increase per week, 3 to 4 hour of increase per week, or more than 4 hours of increase per week). Participants who had not used a PA tracker were asked if they would be interested in using one (yes/no).

\section{Data analysis}

Frequencies were calculated for each of the questions of the questionnaire about interest, use and preferences for PAT. As recommend by IPAQ Research Committee (2005), median and interquartile range (IQR) were used as descriptive statistics for PA variables.

As the data did not have a normal distribution and the median is the best measure of central tendency in the case of the present data, we opted for the use of nonparametric analyses. Kruskal-Wallis Test was used to test the differences in PA levels between participants who used, had used and never used PAT. Post-hoc pairwise comparisons were done with Steel-DwassCritchlow-Fligner test. The level of significance was set at $\mathrm{p}<0.05$.

All data analysis was done with SPSS version 24.0 (IBM Corp. Released 2016. IBM SPSS Statistics for Windows, Version 24.0. Armonk, NY: IBM Corp.)

\section{RESULTS}

\section{Interest and preferences for PAT use}

\section{Exercise practices}

More than a half of participants $(57.1 \%)$ practiced PA/exercise regularly (30.6\% of these were females) and $36.1 \%$ practiced in the past. Only $4.4 \%$ of the adolescents answered that they did not practiced, and $17.8 \%$ of the older adults, $6.1 \%$ and $8.5 \%$ respectively of young adults and middle-age adults, do not regularly do PA/exercise. Only $0.9 \%$ practiced occasionally and $3.6 \%$ once a week.

\section{Use of PAT}

Out of all the participants who practice or practiced in the past PA/exercise regularly, 59\% do not use PAT, $27 \%$ were using, and $14 \%$ have used. The majority of these participants $(80.1 \%)$ acquired the PAT after they started exercising regularly, and $9.7 \%$ think that the PAT had allowed them to increase their PA. Out of all participants who had not used a PAT, $72.4 \%$ would like to use one.

There are a substantial number of participants that used a PAT for 1 to 2 years (20.4\%) and for more than two years $(25.3 \%), 17.4 \%$ only used a PAT for less 


\section{Activity trackers and physical activity}

than one month, $19.4 \%$ for 3 to 4 months, and $17.4 \%$ for 6 to 12 months.

The majority of the participants use the tracker only during exercise practice (73.9\%), $14.4 \%$ use it during waking hours, $11.2 \%$ use it always, and only $0.4 \%$ use it only during the night.

\section{Preferred PAT}

The most frequently used device was mobile applications $(22.2 \%), 11.1 \%$ used heart rate monitors, and $11.4 \%$ used GPS. The most registered parameters were time length of the exercise $(28 \%)$ and distance $(25.6 \%)$, follow by speed $(19.8 \%)$, calories $(19.6 \%)$, and heart rate $(18.4 \%)$. A small number of participants also registered accumulated climb (8.7\%), power $(4.8 \%)$ and $\mathrm{VO} 2(3.1 \%)$.

\section{Perception about the influence of PAT on the motivation for $P A$}

Participants' perception about the possible influence of activity trackers on the motivation for PA/exercise was low, $5 \%$ answered 'yes', $1.5 \%$ answered 'no', and the majority (93.5\%) did not answer the question.

\section{Relationship between PAT use and PA levels.}

Table 2 shows the median and interquartile range (IQR) for PA by sex and age, and the results of Kruskal-Wallis test for the difference in PA between the participants that use, had used and never used PAT.

The Kruskal-Wallis test results show that in male and female adolescents there were only significant differences between the participants who use, had used and never used PAT in vigorous PA in males. Post hoc pairwise comparisons indicate that participants who use PAT did significantly more vigorous PA than participants who had used PAT, and these ones did significantly more vigorous PA than the participants who never used PAT.

In young adults in both males and females, walking was the only level with no significant differences. In all other PA intensity levels participants who use PAT did significantly more PA than participants who had used, and these ones did significantly more than the participants who never used PAT.
In middle-aged female adults, there were no significant differences in walking. In total PA and moderate PA, participants who use PAT did significantly more PA than participants who had used, and these ones did significantly more than the participants who never used PAT.

In middle-aged male adults, participants who use PAT did significantly more total week PA, vigorous PA and walking PA than participants who had used PAT, but the PA levels were similar to those participants who never used PA. In vigorous PA, participants who used PAT did more PA than participants who had used and also more than participants who never used PAT, but participants who never used PAT did more PA than participants who had used PAT.

In older female adults, there was no one who used or had used PAT. In older male adults, there was no one who had used PAT. The only significant difference between participants who use and the participants that never used PAT occurred in vigorous PA, with participants who use PAT having significantly more vigorous $\mathrm{PA}$.

Table 3 shows the median and interquartile range (IQR) for sedentary time by sex and age, and KruskalWallis test results for the difference in sedentary time between the participants who use, had used and never used PAT.

The Kruskal-Wallis test results show that in females the differences between the participants who use, had used and never used PAT occurred in adolescents and young adults. In both cases, participants who had used PAT had significant more sedentary time than participants who never used PAT, and these ones had significant more sedentary time than participants that use PAT.

In males, the differences occurred only in middle-aged adults, and participants who had used PAT had significant more sedentary time than participants who never used PAT, and these ones had significant more sedentary time than participants that use PAT. 


\section{Lopes, Sá}

Table 2. Median and interquartile range (IQR) for physical activity by sex and age, and Kruskal-Wallis test results for the difference in PA between the participants who use, had used and never used PA trackers.

\begin{tabular}{|c|c|c|c|c|c|c|c|c|c|}
\hline & & \multicolumn{2}{|l|}{ Yes (Y) } & \multicolumn{2}{|c|}{ Had used (H) } & \multicolumn{2}{|c|}{ Never used (N) } & \multirow[t]{2}{*}{$\begin{array}{l}\text { Kruskal-Wallis } \\
\mathrm{P} \text { values }\end{array}$} & \multirow[t]{2}{*}{$\begin{array}{l}\text { Significant pairwise } \\
\text { comparisons }\end{array}$} \\
\hline & $\begin{array}{l}\text { activity } \\
\text { (MET- } \\
\text { min/week) }\end{array}$ & Median & IQR & Median & IQR & Median & IQR & & \\
\hline \multirow{5}{*}{$\begin{array}{l}\text { Females } \\
\text { Adolescents } \\
(\mathrm{N}=75)\end{array}$} & & & & & & & & \multirow{5}{*}{ NS } & \\
\hline & Walking & 594 & 297 & 578 & 990 & 495 & 1056 & & \\
\hline & Moderate & 720 & 800 & 300 & 1030 & 480 & 1440 & & \\
\hline & Vigorous & 2880 & 1440 & 720 & 2460 & 960 & 4320 & & \\
\hline & Total week & 4314 & 1440 & 2624 & 2988 & 2772 & 5632 & & \\
\hline \multirow{4}{*}{$\begin{array}{l}\text { Young adults } \\
(\mathrm{N}=607)\end{array}$} & Walking & 495 & 627 & 479 & 776 & 396 & 792 & NS & \\
\hline & Moderate & 480 & 920 & 40 & 720 & 60 & 480 & $<0.001$ & $\mathrm{Y}>\mathrm{N}>\mathrm{H}$ \\
\hline & Vigorous & 1200 & 2040 & 200 & 1920 & 80 & 1440 & $<0.001$ & $\mathrm{Y}>\mathrm{H}>\mathrm{N}$ \\
\hline & Total week & 2540 & 3291 & 1683 & 3192 & 1386 & 2778 & $<0.001$ & $\mathrm{Y}>\mathrm{H}>\mathrm{N}$ \\
\hline \multirow{2}{*}{$\begin{array}{l}\text { Middle-aged } \\
\text { adults } \\
(\mathrm{N}=143)\end{array}$} & Walking & 371 & 512 & 248 & 248 & 297 & 660 & \multirow{2}{*}{$\begin{array}{l}\text { NS } \\
0.05\end{array}$} & \multirow[b]{2}{*}{$\mathrm{Y}>\mathrm{H}>\mathrm{N}$} \\
\hline & Moderate & 420 & 680 & 300 & 240 & 120 & 480 & & \\
\hline \multirow{6}{*}{$\begin{array}{l}\text { Older adults } \\
(\mathrm{N}=16)\end{array}$} & Vigorous & 1440 & 960 & - & - & 0 & 960 & \multirow{2}{*}{$\begin{array}{l}<0.001 \\
0.002\end{array}$} & \multirow{2}{*}{$\begin{array}{l}\mathrm{Y}>\mathrm{N} \\
\mathrm{Y}>\mathrm{N}>\mathrm{H}\end{array}$} \\
\hline & Total week & 2060 & 2160 & 618 & 629 & 1035 & 1689 & & \\
\hline & Walking & - & - & - & - & 198 & 627 & - & \\
\hline & Moderate & - & - & - & - & 720 & 720 & - & \\
\hline & Vigorous & - & - & - & - & 0 & 240 & - & \\
\hline & Total week & - & - & - & - & 1413 & 1460 & - & \\
\hline \multirow{5}{*}{$\begin{array}{l}\text { Males } \\
\text { Adolescents } \\
(\mathrm{N}=60)\end{array}$} & & & & & & & & & \\
\hline & Walking & 462 & 1056 & 396 & 660 & 330 & 396 & \multirow{2}{*}{$\begin{array}{l}\text { NS } \\
\text { NS }\end{array}$} & \\
\hline & Moderate & 720 & 1440 & 160 & 1260 & 360 & 1080 & & \\
\hline & Vigorous & 3600 & 2160 & 2880 & 3240 & 2880 & 3600 & 0.04 & $\mathrm{Y}>\mathrm{H}>\mathrm{N}$ \\
\hline & Total week & 4142 & 4200 & 4572 & 2741 & 3488 & 3040,5 & \multirow{2}{*}{ NS } & \\
\hline \multirow{4}{*}{$\begin{array}{l}\text { Young adults } \\
(\mathrm{N}=440)\end{array}$} & Walking & 462 & 842 & 396 & 660 & 396 & 660 & & \\
\hline & Moderate & 720 & 1200 & 480 & 960 & 240 & 960 & $<0.001$ & $\mathrm{Y}>\mathrm{H}>\mathrm{N}$ \\
\hline & Vigorous & 2160 & 2880 & 1920 & 2400 & 1440 & 2880 & 0.001 & $\mathrm{Y}>\mathrm{H}>\mathrm{N}$ \\
\hline & Total week & 3573 & 3798 & 2880 & 3657 & 2550 & 3212 & $<0.001$ & $\mathrm{Y}>\mathrm{H}>\mathrm{N}$ \\
\hline \multirow{2}{*}{$\begin{array}{l}\text { Middle-aged } \\
\text { adults } \\
(\mathrm{N}=128)\end{array}$} & Walking & 347 & 574 & 149 & 50 & 182 & 792 & 0.007 & $\mathrm{Y}>\mathrm{H} ; \mathrm{Y}=\mathrm{N} ; \mathrm{H}<\mathrm{N}$ \\
\hline & Moderate & 600 & 1020 & 240 & 120 & 100 & 480 & 0.006 & $\mathrm{Y}>\mathrm{H} ; \mathrm{Y}=\mathrm{N} ; \mathrm{H}<\mathrm{N}$ \\
\hline & Vigorous & 1920 & 2400 & 480 & 960 & 840 & 1800 & $<0.001$ & $\mathrm{Y}>\mathrm{H} ; \mathrm{Y}>\mathrm{N} ; \mathrm{H}<\mathrm{N}$ \\
\hline & Total week & 2997 & 3104 & 869 & 1066 & 1396 & 2195 & $<0.001$ & $\mathrm{Y}>\mathrm{H} ; \mathrm{Y}=\mathrm{N} ; \mathrm{H}<\mathrm{N}$ \\
\hline Older adults & Walking & 792 & 1733 & - & - & 594 & 693 & NS & \\
\hline & Moderate & 0 & 1680 & - & - & 720 & 840 & NS & \\
\hline & Vigorous & 1920 & 1280 & - & - & 0 & 1080 & 0.04 & $\mathrm{Y}>\mathrm{N}$ \\
\hline & Total week & 2712 & 4693 & - & - & 2120 & 2646 & NS & \\
\hline
\end{tabular}

Notes: NS= not significant 


\section{Activity trackers and physical activity}

Table 3: Median and interquartile range (IQR) for sedentary time by sex and age, and Kruskal-Wallis test results for the difference in sedentary time between the participants who use, had used and never used PA trackers.

\begin{tabular}{|c|c|c|c|c|c|c|c|c|}
\hline & \multicolumn{2}{|l|}{ Yes $(\mathrm{Y})$} & \multicolumn{2}{|c|}{ Had used $(\mathrm{H})$} & \multicolumn{2}{|c|}{ Never used (N) } & \multirow[t]{2}{*}{$\begin{array}{l}\text { Kruskal-Wallis } \\
\text { p values }\end{array}$} & \multirow{2}{*}{$\begin{array}{l}\text { Significant } \\
\text { pairwise } \\
\text { comparisons }\end{array}$} \\
\hline & Median & IQR & Median & IQR & Median & IQR & & \\
\hline \multicolumn{9}{|l|}{ Females } \\
\hline Adolescents $(\mathrm{N}=75)$ & 4.0 & 5.0 & 9.5 & 4.0 & 6.0 & 4.0 & 0.01 & $\mathrm{H}>\mathrm{N}>\mathrm{Y}$ \\
\hline Young adults $(\mathrm{N}=607)$ & 6.0 & 4.0 & 8.0 & 6.0 & 7.0 & 6.0 & 0.01 & $\mathrm{H}>\mathrm{N}>\mathrm{Y}$ \\
\hline Middle-aged adults $(\mathrm{N}=143)$ & 7.5 & 6.0 & 6.5 & 4.3 & 7.0 & 6.0 & NS & \\
\hline Older adults $(\mathrm{N}=16)$ & - & - & - & - & 3.0 & 5.0 & - & \\
\hline \multicolumn{9}{|l|}{ Males } \\
\hline Adolescents $(\mathrm{N}=60)$ & 6.0 & 2.5 & 7.0 & 8.0 & 6.0 & 3.5 & NS & \\
\hline Young adults $(\mathrm{N}=440)$ & 5.0 & 5.0 & 5.0 & 4.0 & 6.0 & 6.0 & NS & \\
\hline Middle-aged adults $(\mathrm{N}=128)$ & 6.0 & 3.0 & 9.8 & 5.5 & 6.0 & 4.0 & 0.04 & $\mathrm{H}>\mathrm{N}>\mathrm{Y}$ \\
\hline Older adults $(\mathrm{N}=29)$ & 2.0 & 3.0 & & 0.0 & 4.0 & 3.0 & NS & \\
\hline
\end{tabular}

\section{DISCUSSION}

The purposes of this study were to study the use of PAT and to analyse the relationship between its use and habitual PA levels.

We found that the majority of the participants do exercise regularly and about half of them use PAT during the practice, which demonstrate that participants have some interest in using PAT and in monitoring the exercise. The majority of these participants acquired the PAT after they started exercise regularly and use it mainly during exercise practice. And the majority of those who did not own a PAT $(72.4 \%)$ would like to have and use one. The results are quite similar to those found by Alley et al. (2016) in a survey conducted in Australia, where it was found that $35 \%$ of participants had used a tracker, and $16 \%$ were interested in using one. In a survey conducted in Alberta (Canada), the use was less prevalent (19.6\%), although nearly one-third of the participants owned a PAT (Macridis et al., 2018), and just over $10 \%$ were planning to use one in the future.

There is a wide variety of commercial PAT available to consumers for personal use. The number of connected wearable devices worldwide has more than doubled in the space of three years, increasing from 325 million in 2016 to 722 million in 2019 (Tankovska, 2020b). Revenue from PAT device sales are forecast to amount to around 3.30 billion U.S. dollars by 2022 (Tankovska, 2020a). The increase of wearable technology maybe is associated with the increase of running practitioners around the world (López et al., 2017). Although relatively few have been tested in order to determine their acceptability, usefulness, efficacy or effectiveness in promoting health. The most frequently used PAT by the participants of the present study was mobile application, maybe because everyone has a mobile phone and apps are cheaper (sometimes free of charge) than a physical PAT. Anyway, in Australia the most frequently used tracker was a pedometer (Alley et al., 


\section{Lopes, Sá}

2016), and in Alberta (Canada) the most frequently used tracker was a specific brand of a band to wear on the wrist.

The most popular function of the trackers was the 'time length of the exercise', 'speed', and 'distance', followed by 'calories' and 'hearth rate'. Similarly, in the Alley et al. (2016) study the most useful functions were distance, types of activity, and tracking steps. These functions, except 'calories' and 'hearth rate', are easy to understand, measure and interpret, and they can be motivational to increase PA (Bravata et al., 2007). 'Heart rate' can be used as an indicator of exercise intensity (Ekelund et al., 2002) and maybe most of the participants use this function for that reason. In fact, the majority of the participants do exercise regularly and maybe some of theme control the exercise intensity by measuring the heart rate.

Among a wide range of factors related to adherence to PA, motivation is considered a key factor (Fortier et al., 2012; Quested et al., 2017; Rodrigues et al., 2020; Silva et al., 2010; Zhong \& Wang, 2019)., and PAT could be a motivation factor. PAT devices and apps are of interest for use in scalable PA interventions because they can encourage the use of theory-driven self-regulation skills known to be associated with behaviour change success (Michie et al., 2009). The use of a PAT has the potential to increase physical activity participation (Brickwood et al., 2019). For instance the use of a PAT in a intervention program in postmenopausal women was associated with increased PA 16 weeks later. However, were found that providing an accelerometer in a intervention PA program in older adults ( $>65$ years) did not result in a significant improvement in activity levels (Thompson et al., 2014). According Coughlin and Stewart (2016) systematic review in initial trials, consumer wearable devices (PAT) have been shown to increase PA. However, the number of studies completed to date is small and limited by small sample sizes, short study durations, and uncertain generalizability of the findings.(Coughlin \& Stewart, 2016). In the present study the participants' perception about influence of PAT on the motivation for PA/exercise was low. Nevertheless, the majority of the participants that do not have a PAT would like to have one.

We found that in general, participants who use PAT had more habitual PA, compared to those who had used and who never used PAT. The amount of sedentary time was higher among participants that never used and had used PAT compared to those who use PAT. In some age groups, especially in adolescents, there was no association between the use of a PAT and walking. However, we found that all participants that use a PAT had significant more vigorous PA than participants that had used and the ones that never have used a PAT. Similar results were found by Macridis et al. (2018), as they found that the use of PAT was significantly associated with meeting PA guidelines. Wearable devices offer a useful approach for monitoring PA in both clinical research involving patient populations and community-based research (Yingling, et al., 2016). A systematic review and meta-analysis study (Hannan et al., 2019) on the impact of PAT to monitoring exercise prescription or advice in cardiac rehabilitation shown that in $70 \%$ of studies, step count was greater in participants using a PAT with exercise prescription or advice, however the overall effect was not significant. Similar results were found by Gal et al. (2018). They found that the use of wearables and smartphone applications led to a small to moderate increase in physical activity in minutes per day and a moderate increase in daily step count.

Despite the results found in the present research, we could not confirm our hypothesis, saying that the use of a PAT led to the increasing of PA levels. In fact, in the present study most of the participants acquired the PAT after they started exercise regularly, and very few of them think that a PAT allows them to increase PA levels. Therefore, it is plausible that the participants that do exercise regularly feel more desire and motivation to purchase a PAT and not the opposite. This suggestion is seconded by at least two randomized control trials (Finkelstein et al., 2016; Kim et al., 2018). Finkelstein et al. (2016) did not found effectiveness of PAT to increase PA in adults (aged 21-65 years). Also Kim et al. (2018) in a randomized controlled trial with college students founded that utilizing a modern, wearable activity tracker was not effective in promoting habitual levels of PA. It is possible to find opposite results in older studies with pedometers. A systematic review Bravata et al. (2007) found that the use of a pedometer was associated with significant increases in PA.

It can be seen that little research has examined whether PAT are a feasible and effective method for changing physical activity behaviours in the short- and long- 


\section{Activity trackers and physical activity}

term. According to Turner-McGrievy et al. (2018), the allurement of using a PAT is partly enlightened by cognitive load theory [the more cognitive burden, or mental concentration, users experience, the less able they will be to retain and act on what they learned (Brunken et al., 2003) and user control theory [an increase in the variety of different ways to access information enhances the sense of control of the user, and therefore increases learning (Eveland \& Dunwoody, 2001). PAT have the potential to simultaneously achieve reductions in cognitive load through easy interfaces and automatic tracking, as well as increasing user control, by allowing users to view feedback on the device. There is a need for research that examines the long-term use of PAT and whether this technology has any positive effect on levels of PA.

This study is not without limitations; the main limitation is that the survey sample was no randomly selected. In fact, this is a convenience sample recruited with a kind of snowball sampling method. Anyway, the magnitude of the sample and the wide spectrum of residence regions of the participants are aspects that allow to generalize the results. In fact, this study is unique in the way that it was recruited a large sample from all over the country, which is hard to achieve.

\section{CONCLUSIONS}

About half of the participants that exercise regularly use PAT during the practice, and the ones that do not have one would like to have. Despite participants that use a PAT tend to have higher levels of habitual PA, it is not conclusive that the use of a PAT leads one to do more PA. Anyway, wearable technologies are innovative platforms for behavioural modifications and obesity prevention in public health that encourages users to engage in physical activities aided by technological assistance.

\section{PRATICAL APPLICATION}

The use of PAT could be a tool for PA promotion both in general populations and in specific PA interventions programs. PAT are likely to bring new opportunities in effective interventions to increase levels of PA.

\section{REFERENCES}

Ahroni, J. H. (1996). Strategies for teaching elders from a human development perspective. Diabetes Educ,
22(1), 47-52; $\quad$ quiz $53-44$. https://doi.org/10.1177/014572179602200107

Alley, S., Schoeppe, S., Guertler, D., Jennings, C., Duncan, M. J., \& Vandelanotte, C. (2016). Interest and preferences for using advanced physical activity tracking devices: results of a national crosssectional survey. BMJ Open, 6(7). https://doi.org/10.1136/bmjopen-2016-011243

Añez, E., Fornieles Deu, A., \& Sánchez Carracedo, D. (2020). Longitudinal study of physical activity in Spanish young adolescents : weight status and gender difference. Revista de psicología del deporte, 29(1), 57-66.

Bauman, A. E., Sallis, J. F., Dzewaltowski, D. A., \& Owen, N. (2002). Toward a better understanding of the influences on physical activity. American Journal of Preventive Medicine, 23(2), 5-14. https://doi.org/10.1016/s0749-3797(02)00469-5

Bravata, D. M., Smith-Spangler, C., Sundaram, V., \& et al. (2007). Using pedometers to increase physical activity and improve health: A systematic review. JAMA， 298(19), 2296-2304. https://doi.org/10.1001/jama.298.19.2296

Brickwood, K.-J., Watson, G., O'Brien, J., \& Williams, A. D. (2019). Consumer-Based Wearable Activity Trackers Increase Physical Activity Participation: Systematic Review and Meta-Analysis. JMIR Mhealth Uhealth, 7(4), e11819. https://doi.org/10.2196/11819

Brunken, R., Plass, J. L., \& Leutner, D. (2003). Direct Measurement of Cognitive Load in Multimedia Learning. Educational Psychologist, 38(1), 53-61. https://doi.org/10.1207/S15326985EP3801_7

Cadmus-Bertram, L. A., Marcus, B. H., Patterson, R. E., Parker, B. A., \& Morey, B. L. (2015). Randomized Trial of a Fitbit-Based Physical Activity Intervention for Women. American Journal of Preventive Medicine, 49(3), 414-418. https://doi.org/10.1016/j.amepre.2015.01.020

Coughlin, S. S., \& Stewart, J. (2016). USE OF CONSUMER WEARABLE DEVICES TO PROMOTE PHYSICAL ACTIVITY: A REVIEW OF HEALTH INTERVENTION STUDIES. Journal of Environment and Health Science, 2(6), 1-6. https://doi.org/10.15436/2378-6841.16.1123

Craig, C. L., Marshall, A. L., Sjöström, M., Bauman, A. E., Booth, M. L., Ainsworth, B. E., Pratt, M., Ekelund, U., Yngve, A., Sallis, J. F., \& Oja, P. (2003). International Physical Activity Questionnaire: 12Country Reliability and Validity. Medicine and Science in Sports and Exercise, 35(8), 1381-1395. https://doi.org/10.1249/01.MSS.0000078924.614 53.FB

David, R. B. (2012). Device-based monitoring in physical activity and public health research. Physiological 


\section{Lopes, Sá}

Measurement, $\quad 33(11), \quad 1769$. https://doi.org/10.1088/0967-3334/33/11/1769

Delle Fave, A., Bassi, M., Boccaletti, E. S., Roncaglione, C., Bernardelli, G., \& Mari, D. (2018). Promoting Well-Being in Old Age: The Psychological Benefits of Two Training Programs of Adapted Physical Activity. Frontiers in Psychology, 9. https://doi.org/10.3389/fpsyg.2018.00828

Diego, G.-B., R. Mendoza, R., \& Tomico, A. (2018). The prospective relationship of sport and physical activity with life satisfaction after a one-year follow-up: an examination of gender differences during mid-adolescence. Cuadernos de Psicología del Deporte, 18(2). https://revistas.um.es/cpd/article/view/302711

Ding, D., Lawson, K. D., Kolbe-Alexander, T. L., Finkelstein, E. A., Katzmarzyk, P. T., van Mechelen, W., \& Pratt, M. (2016). The economic burden of physical inactivity: a global analysis of major non-communicable diseases. Lancet, 388(10051), 1311-1324. https://doi.org/10.1016/S0140-6736(16)30383-X

Ekelund, U., Yngve, A., Westerterp, K., \& Sjöström, M. (2002). Energy expenditure assessed by heart rate and doubly labeled water in young athletes. Medicine and Science in Sport and Exercise, 34(8), 1360. https://doi.org/10.1097/00005768200208000-00019

Erikson, E. H., \& Erikson, J. M. (1998). The Life Cycle Completed (Extended Version). W. W. Norton. https://books.google.pt/books?id=SKidSuluprgC

Eveland, W. P., \& Dunwoody, S. (2001). User Control and Structural Isomorphism or Disorientation and Cognitive Load?: Learning From the Web Versus Print. Communication Research, 28(1), 48-78. https://doi.org/10.1177/009365001028001002

Finkelstein, E. A., Haaland, B. A., Bilger, M., Sahasranaman, A., Sloan, R. A., Nang, E. E. K., \& Evenson, K. R. (2016). Effectiveness of activity trackers with and without incentives to increase physical activity (TRIPPA): a randomised controlled trial. Lancet Diabetes \& Endocrinology, 4(12), 983-995. https://doi.org/10.1016/S22138587(16)30284-4

Fortier, M. S., Duda, J. L., Guerin, E., \& Teixeira, P. J. (2012). Promoting physical activity: development and testing of self-determination theory-based interventions. International Journal of Behavioral Nutrition and Physical Activity, 9(1), 20. https://doi.org/10.1186/1479-5868-9-20

Gal, R., May, A. M., Van Overmeeren, E. J., Simons, M., \& Monninkhof, E. M. (2018). The Effect of Physical Activity Interventions Comprising Wearables and Smartphone Applications on Physical Activity: a Systematic Review and Meta-analysis. Sports
Medicine
https://doi.org/10.1186/s40798-018-0157-9

Guthold, R., Stevens, G. A., Riley, L. M., \& Bull, F. C. (2020). Global trends in insufficient physical activity among adolescents: a pooled analysis of 298 population-based surveys with 1.6 million participants. The Lancet Child \& Adolescent Health, 4(1), 23-35. https://doi.org/10.1016/s2352-4642(19)30323-2

Hagströmer, M., Bergman, P., De Bourdeaudhuij, I., Ortega, F. B., Ruiz, J. R., Manios, Y., Rey-López, J. P., Phillipp, K., von Berlepsch, J., Sjöström, M., \& Group., H. S. (2008). Concurrent validity of a modified version of the International Physical Activity Questionnaire (IPAQ-A) in European adolescents: The HELENA Study. International Journal of Obesity, 32(Suppl 5), S42-48. https://doi.org/10.1038/ijo.2008.182.

Hallal, P. C., Andersen, L. B., Bull, F. C., Guthold, R., Haskell, W., \& Ekelund, U. (2012). Global physical activity levels: surveillance progress, pitfalls, and prospects. Lancet, 380(9838), 247$257 . \quad$ https://doi.org/10.1016/S01406736(12)60646-1

Hannan, A. L., Harders, M. P., Hing, W., Climstein, M., Coombes, J. S., \& Furness, J. (2019). Impact of wearable physical activity monitoring devices with exercise prescription or advice in the maintenance phase of cardiac rehabilitation: systematic review and meta-analysis. BMC Sports Science, Medicine and Rehabilitation, 11(1). https://doi.org/10.1186/s13102-019-0126-8

Heath, G. W., Parra, D. C., Sarmiento, O. L., Andersen, L. B., Owen, N., Goenka, S., Montes, F., \& Brownson, R. C. (2012). Evidence-based intervention in physical activity: lessons from around the world. The Lancet, 380(9838), 272281. 6736(12)60816-2 https://doi.org/10.1016/s0140-

Herbert, C., Meixner, F., Wiebking, C., \& Gilg, V. (2020). Regular Physical Activity, Short-Term Exercise, Mental Health, and Well-Being Among University Students: The Results of an Online and a Laboratory Study. Frontiers in Psychology, 11. https://doi.org/10.3389/fpsyg.2020.00509

IPAQ Research Committee. (2005). Guidelines for Data Processing and Analysis of the International Physical Activity Questionnaire (IPAQ)-Short and Long Forms. http://www.ipaq.ki.se/scoring.pdf. https://ci.nii.ac.jp/naid/10030318551/en/

Janssen, I., \& LeBlanc, A. (2010). Systematic review of the health benefits of physical activity and fitness in school-aged children and youth. International Journal of Behavioral Nutrition and Physical 


\section{Activity trackers and physical activity}

Activity, 7(1), 40. https://doi.org/10.1186/1479$\underline{5868-7-40}$

Katzmarzyk, P. T., Denstel, K. D., Beals, K., Bolling, C., Wright, C., Crouter, S. E., McKenzie, T. L., Pate, R. R., Saelens, B. E., Staiano, A. E., Stanish, H. I., \& Sisson, S. B. (2016). Results From the United States of America's 2016 Report Card on Physical Activity for Children and Youth. Journal of Physical Activity and Health, 13(s2), S307-S313. https://doi.org/10.1123/jpah.2016-0321

Kim, Y., Lumpkin, A., Lochbaum, M., Stegemeier, S., \& Kitten, K. (2018). Promoting physical activity using a wearable activity tracker in college students: A cluster randomized controlled trial. Journal of Sports Sciences, 36(16), 1889-1896. https://doi.org/10.1080/02640414.2018.1423886

Laura, G., \& Fabio, L. (2016). A Self-determination theory based intervention to promote healthy eating and physical activity in school-aged children. Cuadernos de Psicología del Deporte, 16(3). https://revistas.um.es/cpd/article/view/278391

Lawton, E., Brymer, E., Clough, P., \& Denovan, A. (2017). The Relationship between the Physical Activity Environment, Nature Relatedness, Anxiety, and the Psychological Well-being Benefits of Regular Exercisers. Frontiers in Psychology, 8. https://doi.org/10.3389/fpsyg.2017.01058

Lee, I. M., Shiroma, E. J., Lobelo, F., Puska, P., Blair, S. N., \& Katzmarzyk, P. T. (2012). Effect of physical inactivity on major non-communicable diseases worldwide: an analysis of burden of disease and life expectancy. The Lancet, 380(9838), 219 - 229. https://doi.org/10.1016/S0140-6736(12)61031-9

López, A. N., Valle, A. S. d., \& Rosa, S. M. (2017). Adicción a correr: una revisión desde sus inicios hasta la actualidad. Revista de Psicología Aplicada al Deporte y al Ejercicio Físico (2017), 1, e6, 1 22, 2(1), e6, 1-22. https://doi.org/10.5093/rpadef2017a1

Macridis, S., Johnston, N., Johnson, S., \& Vallance, J. K. (2018). Consumer physical activity tracking device ownership and use among a populationbased sample of adults. PLoS One, 13(1), e0189298-e0189298.

https://doi.org/10.1371/journal.pone.0189298

Matthews, C. E., Chen, K. Y., Freedson, P. S., Buchowski, M. S., Beech, B. M., Pate, R. R., \& Troiano, R. P. (2008). Amount of Time Spent in Sedentary Behaviors in the United States, 2003-2004. American Journal of Epidemiology, 167(7), 875881. https://doi.org/10.1093/aje/kwm390

Michie, S., Abraham, C., Whittington, C., McAteer, J., \& Gupta, S. (2009). Effective techniques in healthy eating and physical activity interventions: A meta- regression. Health Psychology, 28(6), 690-701. https://doi.org/10.1037/a0016136

Moral-Campillo, L., Reigal Garrido, R. E., \& Hernández Mendo, A. (2020). Actividad física, funcionamiento cognitivo y psicosocial en una muestra preadolescente. Revista de psicología del deporte, 29(1), 123-132. https://doi.org/10.5672/apunts.20140983.es.(2015/3).121.03

Mota, J., Coelho-E-Silva, M. J. O., Raimundo, A. M., \& Sardinha, L. B. (2016). Results From Portugal's 2016 Report Card on Physical Activity for Children and Youth. Journal of Physical Activity and Health, 13(s2), S242-S245. https://doi.org/10.1123/jpah.2016-0293

Quested, E., Ntoumanis, N., Thøgersen-Ntoumani, C., Hagger, M. S., \& Hancox, J. E. (2017). Evaluating quality of implementation in physical activity interventions based on theories of motivation: current challenges and future directions. International Review of Sport and Exercise Psychology, 10(1), 252-269. https://doi.org/10.1080/1750984x.2016.1217342

Reiner, M., Niermann, C., Jekauc, D., \& Woll, A. (2013). Long-term health benefits of physical activity - a systematic review of longitudinal studies. $B M C$ Public Health, 13(1), 813. https://doi.org/10.1186/1471-2458-13-813

Rodrigues, F., Cid, L., Forte, P., Gonçalves, C., Machado, S., Neiva, H., Teixeira, D., \& Monteiro, D. (2020). A perceção de divertimento em jovens, adultos e idosos: um estudo comparativo. Cuadernos de Psicología del Deporte, 20(2), 26-36. https://doi.org/10.6018/cpd.403391

Roman-Viñas, B., Marin, J., Sánchez-López, M., Aznar, S., Leis, R., Aparicio-Ugarriza, R., Schroder, H., Ortiz-Moncada, R., Vicente, G., González-Gross, M., \& Serra-Majem, L. (2016). Results From Spain's 2016 Report Card on Physical Activity for Children and Youth. Journal of Physical Activity and Health, 13(s2), S279-S283. https://doi.org/10.1123/jpah.2016-0308

Silva, M. N., Markland, D., Vieira, P. N., Coutinho, S. R., Carraça, E. V., Palmeira, A. L., Minderico, C. S., Matos, M. G., Sardinha, L. B., \& Teixeira, P. J. (2010). Helping overweight women become more active: Need support and motivational regulations for different forms of physical activity. Psychology of Sport and Exercise, 11(6), 591-601. https://doi.org/10.1016/j.psychsport.2010.06.011

Tankovska, H. (2020a). Fitness tracker device revenue worldwide 2016-2022. Retrieved 24 September 2020 from https://www.statista.com/statistics/610433/wearab le-healthcare-device-revenue-worldwide/ 


\section{Lopes, Sá}

Tankovska, H. (2020b). Number of connected wearable devices worldwide from 2016 to 2022. Retrieved $24 \quad$ September 2020 from https://www.statista.com/statistics/487291/globalconnected-wearable-devices/

Thompson, W. G., Kuhle, C. L., Koepp, G. A., McCradySpitzer, S. K., \& Levine, J. A. (2014). "Go4Life" exercise counseling, accelerometer feedback, and activity levels in older people. Archives of Gerontology and Geriatrics, 58(3), 314-319. https://doi.org/10.1016/j.archger.2014.01.004

Trost, S. G., Owen, N., Bauman, A. E., Sallis, J. F., \& Brown, W. (2002). Correlates of adults' participation in physical activity: review and update. Medicine and Science in Sports and Exercise, 34(12), 1996. https://doi.org/10.1097/00005768-200212000$\underline{00020}$

Turner-McGrievy, G., Jake-Schoffman, D. E., Singletary, C., Wright, M., Crimarco, A., Wirth, M. D., Shivappa, N., Mandes, T., West, D. S., Wilcox, S., Drenowatz, C., Hester, A., \& McGrievy, M. J. (2018). Using Commercial Physical Activity Trackers for Health Promotion Research: Four Case Studies. Health Promotion Practice, 1524839918769559. https://doi.org/10.1177/1524839918769559

Van Sluijs, E. M. F., McMinn, A. M., \& Griffin, S. J. (2007). Effectiveness of interventions to promote

\section{ACKNOWLEDGING}

This work was supported by national funding through the Portuguese Foundation for Science and Technology, I.P., under project UID04045/2020

\section{DECLARATION OF INTEREST STATEMENT}

The authors declare that they have no conflict of interest. physical activity in children and adolescents: systematic review of controlled trials. $B M J$, 335(7622), 703. https://doi.org/10.1136/bmj.39320.843947.be

Wahlich, C., Chaudhry, U. A. R., Fortescue, R., Cook, D. G., Hirani, S., Knightly, R., \& Harris, T. (2019). Long-term follow-up and objective physical activity measurements of community-based physical interventions in adults: a systematic review and meta-analysis. The Lancet, 394, S96. https://doi.org/10.1016/s0140-6736(19)32893-4

Wen, D., Zhang, X., \& Lei, J. (2017). Consumers' perceived attitudes to wearable devices in health monitoring in China: A survey study. Computer Methods and Programs in Biomedicine, 140, 131-137. https://doi.org/10.1016/j.cmpb.2016.12.009

WHO. (2014). Physical activity. Fact sheet $N^{\circ} 385$. Retrieved 15-04-2014 from http://www.who.int/mediacentre/factsheets/fs385/ en/

WHO. (2018). Global action plan on physical activity 2018 - 2030: more active people for a healthier world. World Health Organization.

Zhong, T., \& Wang, H. (2019). Motivation Profiles for Physical Activity Among Office Workers. Frontiers in Psychology, 10. https://doi.org/10.3389/fpsyg.2019.01577 